\title{
ARSITEKTUR ISLAM: Seni Ruang dalam Peradaban Islam
}

\author{
Aulia Fikriarini \\ Jurusan Teknik Arsitektur Fakultas Sains dan Teknologi, Universitas Islam Negeri Malang, \\ Jalan Gajayana No 50 Telp. 0341-551354, e-mail auliaf_yahya@yahoo.com
}

\section{Abstract}

Human being as a caliph, here related to the function of architect, has responsibility for the environment. Hence, in doing their activities in this world, they have to cope with the nature considering the principal of balance and harmony. Architecture as one of the sciences should also go along with the Islamic values. The values based on the Quran should certainly be the foundation for all efforts of developing any sciences, including architectur. The application of Islam values will produce works of "Islamic architecture" that comprise a combination of culture and humans' submission to their God, which characterizes the harmony of the human beings, environment, and their Creator. Islamic architecture suggests a complex geometrical relation, hierarchy of shapes and ornaments, and deep symbolic meaning. This writing describes the fact that works of Islamic architectures in over the world that is based on Islamic ethical values and manners do not represent a single and identical shape. However, the varieties and wealth of shapes are unfield by one purpose, that is, as a medium of devoting to God. The varieties create a multitude of Islamic architecture products within Islamic civilization, which lead human beings to rahmatan lil alamiin.

Key words: the Quran, values, Islamic architecture 


\section{Pendahuluan}

Kehadiran arsitektur berawal dari manfaat dan kebutuhan-kebutuhan sebuah bangunan untuk melayani fungsi-fungsi tertentu, yang diekspresikan oleh seorang arsitek melalui gambar kerja. Kebutuhan sebuah bangunan akan ruang-ruang dalam lingkup interior maupun eksterior, bermula pada sebuah kebutuhan dari pengguna bangunan (Fikriarini dkk., 2006: 7). Selain itu, arsitektur juga merupakan bagian dari seni, karena arsitektur tidak lepas dari rasa. Hal ini menyebabkan pengertian arsitektur terus berkembang dan dipengaruhi oleh cara berpikir, cara membuat, cara meninjau, dan budaya.

Definisi arsitektur baru akan dapat dimengerti setelah kita mengalami arsitektur atau berarsitektur. Berarsitektur artinya berbahasa dengan ruang dan gatra, dengan garis dan bidang, dengan bahan material dan suasana tempat. Berarsitektur adalah berbahasa manusiawi; dengan citra unsur-unsurnya, baik dengan bahan material maupun dengan bentuk serta komposisinya. Dalam berarsitektur, seorang arsitek tidak pernah lepas dari alam, lingkungan sekitar, dan budaya setempat. Hal ini disebabkan karena arsitektur merupakan bagian dari budaya yang menunjukkan tingkat peradaban manusia. Budaya manusia tersebut sangat dipengaruhi oleh alam, dan karenanya arsitektur dengan sendirinya juga merupakan bagian dari alam, mampu membaca alam dan menciptakan sebuah suasana.

Beberapa pengertian arsitektur terkait dengan karya arsitek, baik itu berupa olahan fungsi ke dalam bentuk dan ruang yang terangkum menjadi satu. Fungsi merupakan pengertian yang sederhana dari kegunaan. Fungsi juga dapat dimaknai sebagai suatu cara untuk memenuhi keinginan yang timbul akibat adanya kebutuhan manusia dalam mempertahankan dan mengembangkan hidupnya (www.library.gunadarma.ac.id). Walaupun begitu, karya arsitektur bukanlah sekedar masalah fungsi, ruang dan bentuk. Lebih dari itu, arsitektur mampu merangkum seni dalam satu bagian yang utuh untuk menghadirkan sebuah keindahan (Fikriarini dkk., 2006: 10-11).

Arsitektur sebagai salah satu bidang keilmuan, hendaknya juga selalu berpijak pada nilai-nilai Islam yang bersumber pada al Quran. Al Quran tentunya merupakan dasar bagi pengembangan berbagai bidang keilmuan, salah satunya keilmuan arsitektur. Wujud arsitektur yang muncul sebagai hasil kreasi seorang arsitek, hendaknya melambangkan nilai-nilai Islam. Artinya, wujud arsitektur yang dihasilkan tidak bertentangan dengan prinsip tauhid, ketentuan syariah, dan tentu saja nilai-nilai akhlakul karimah. Kita dapat melihat karya-karya arsitektur Islam di berbagai belahan dunia dengan tujuan 
yang satu, yaitu untuk beribadah dan berserah diri kepada Allah. Walaupun demikian, dalam tataran bentuk arsitektur Islam yang dilandasi oleh kesatuan tujuan dan nilai-nilai islami itu tidak hadir dalam representasi bentuk fisik yang satu dan seragam, melainkan hadir dalam bahasa arsitektur yang beragam.

Ditinjau secara keseluruhan, arsitektur telah muncul di mana dia dibutuhkan serta tidak terbatas di mana dia didirikan. Arsitektur pun turut mempengaruhi muncul dan tenggelamnya suatu kebudayaan dan peradaban. Masyarakat muslim sebagai salah satu peradaban terbesar di dunia pun tidak ketinggalan dalam menyemarakkan peradaban dengan arsitektur yang mencerminkan worldview dan nilai-nilai Islam sepanjang sejarah perkembangan dan perjalanannya di muka bumi ini. Dalam Islam, arsitektur merupakan bagian dari karya seni yang tidak pernah lepas dari keindahan yang merujuk pada kebesaran Allah sebagai Sang Maha Pencipta. Hal ini memberi kesadaran, bahwa kita sebagai manusia hanyalah hamba yang kecil dan tidak berarti apa-apa dibandingkan dengan kebesaran Alah. Bahkan lebih jauh, rasa kekaguman kita terhadap keindahan dan estetika dalam arsitektur tak boleh lepas dari kepasrahan dan penyerahan diri kita terhadap kebesaran dan keagungan Allah sebagai Dzat pemilik segala keindahan.

\section{Arsitektur Islam}

Arsitektur Islam merupakan wujud perpaduan antara kebudayaan manusia dan proses penghambaan diri seorang manusia kepada Tuhannya, yang berada dalam keselarasan hubungan antara manusia, lingkungan dan Penciptanya. Arsitektur Islam mengungkapkan hubungan geometris yang kompleks, hirarki bentuk dan ornamen, serta makna simbolis yang sangat dalam. Arsitektur Islam merupakan salah satu jawaban yang dapat membawa pada perbaikan peradaban. Di dalam Arsitektur Islam terdapat esensi dan nilai-nilai Islam yang dapat diterapkan tanpa menghalangi pemanfaatan teknologi bangunan modern sebagai alat dalam mengekspresikan esensi tersebut.

Perkembangan arsitektur Islam dari abad VII sampai abad XV meliputi perkembangan struktur, seni dekorasi, ragam hias dan tipologi bangunan. Daerah perkembangannya meliputi wilayah yang sangat luas, meliputi Eropa, Afrika, hingga Asia tenggara. Karenanya, perkembangannya di setiap daerah berbeda dan mengalami penyesuaian dengan budaya dan tradisi setempat, serta kondisi geografis. Hal ini tidak terlepas dari kondisi alam yang mempengaruhi proses terbentuknya kebudayaan manusia. 
Arsitektur yang merupakan bagian dari budaya, selalu berkembang seiring dengan berkembangnya peradaban manusia. Oleh karena itu, Islam yang turut membentuk peradaban manusia juga memiliki budaya berarsitektur. Budaya arsitektur dalam Islam dimulai dengan dibangunnya Ka'bah oleh Nabi Adam as sebagai pusat beribadah umat manusia kepada Allah SWT (Saoud, 2002: 1). Ka'bah juga merupakan bangunan yang pertama kali didirikan di bumi. Tradisi ini dilanjutkan oleh Nabi Ibrahim AS bersama anaknya, Nabi Ismail as. Mereka berdua memugar kembali bangunan Ka'bah. Setelah itu, Nabi Muhammad SAW melanjutkan misi pembangunan Ka'bah ini sebagai bangunan yang bertujuan sebagai tempat beribadah kepada Allah. Dari sinilah budaya arsitektur dalam Islam terus berkembang dan memiliki daya dorong yang belum pernah terjadi sebelumnya, serta mencapai arti secara fungsional dan simbolis. Hal ini dijelaskan dalam al Quran Surat Ali Imran ayat 96: "Sesungguhnya rumah yang mula-mula dibangun untuk (tempat beribadat) manusia, ialah Baitullah yang di Bakkah (Makkah) yang diberkahi dan menjadi petunjuk bagi semua manusia”.

Dari paparan di atas dapat disimpulkan bahwa arsitektur Islam adalah cara membangun yang Islami sebagaimana ditentukan oleh hukum syariah, tanpa batasan terhadap tempat dan fungsi bangunan, namun lebih kepada karakter Islaminya dalam hubungannya dengan desain bentuk dan dekorasi. Definisi ini adalah suatu definisi yang meliputi semua jenis bangunan, bukan hanya monumen ataupun bangunan religius (Saoud, 2002: 2).

Sebagaimana telah kita ketahui bersama, Arsitektur Islam merupakan salah satu gaya arsitektur yang menampilkan keindahan yang kaya akan makna. Setiap detailnya mengandung unsur simbolisme dengan makna yang sangat dalam. Salah satu makna yang terbaca pada arsitektur Islam itu adalah bahwa rasa kekaguman kita terhadap keindahan dan estetika dalam arsitektur tidak terlepas dari kepasrahan dan penyerahan diri kita terhadap kebesaran dan keagungan Allah sebagai Dzat yang memiliki segala keindahan. Bahkan sejak jaman Nabi Sulaiman as, telah dibangun suatu karya arsitektur yang menampilkan keindahan dan kemegahan itu. Hal ini tertuang dalam al Quran Surat an Naml 44: "Dikatakan kepadanya: "Masuklah ke dalam istana". Maka tatkala dia melihat lantai istana itu, dikiranya kolam air yang besar, dan disingkapkannya kedua betisnya. Berkatalah Sulaiman: "Sesungguhnya ia adalah istana licin terbuat dari kaca". Berkatalah Balqis: "Ya Tuhanku, Sesungguhnya aku telah berbuat zalim terhadap diriku dan aku berserah diri bersama Sulaiman kepada Alah, Tuhan semesta alam”. 
Dengan segala keindahan, kemegahan, dan kedalaman maknanya, arsitektur Islam yang pernah berjaya dan menjadi salah satu tonggak peradaban dunia memiliki beberapa potensi yang dapat mencerahkan kembali kejayaan Islam yang selama beberapa abad terakhir ini mengalami kemunduran. Potensi-potensi ini bukan hanya ditujukan untuk menghadapi pengaruh dari kebudayaan barat yang mengglobal dan menginginkan persamaan identitas dari berbagai budaya, namun juga untuk kepentingan pengembangan arsitektur Islam sendiri.

Lebih jauh, apabila kita telaah secara mendalam, arsitektur Islam lebih mengusung pada nilai-nilai universal yang dimuat oleh ajaran Islam. Nilai-nilai ini nantinya dapat diterjemahkan ke dalam bahasa arsitektur dan tampil dalam berbagai bentuk tergantung konteksnya, dengan tidak melupakan esensi dari arsitektur itu sendiri, serta tetap berpegang pada tujuan utama proses berarsitektur, yaitu sebagai bagian dari beribadah kepada Allah.

\section{Al Quran dan Seni}

Di dalam perkembangan kebudayaan dan peradaban Islam, tujuan akhir dari berbagai keilmuan harus dilihat dan didasarkan pada al Quran al Karim, kitab suci umat Islam. Pada dasarnya, kebudayaan Islam dengan arsitektur Islam sebagai salah satu bagiannya, merupakan "budaya Qurani" (Al Faruqi, 1999: 3). Karenanya, baik definisi, struktur, tujuan maupun metode untuk mencapai tujuan tersebut secara keseluruhan diambil darinya.

Dari al Quran yang menjadi tuntunan, panduan hidup dan sumber keilmuan bagi umat Nabi Muhammad ini, seorang muslim tidak hanya mengambil pengetahuan mengenai Realitas Ultima (Al Faruqi, 1999: 3). Secara mendasar, prinsip-prinsip yang diambil dari al Quran juga mencakup tentang alam, manusia, dan makhluk hidup lainnya. Berbagai ilmu pengetahuan juga tercantum dalam al Quran, baik secara implisit maupun eksplisit di berbagai institusi sosial, politik serta ekonomi yang diperlukan untuk menjalankan masyarakat yang sehat, sehingga al Quran diperlukan di setiap pengetahuan dan aktivitas manusia, termasuk juga di bidang keilmuan arsitektur. Di dalam kitab itu, prinsip-prinsip dasar sudah disediakan bagi pembentukan sebuah kebudayaan yang lengkap, tentu saja termasuk bidang arsitektur.

Hal bukan berarti bahwa penjelasan dan uraian yang spesifik dan jelas tentang berbagai usaha manusia tersebut telah termuat dalam kitab suci yang memuat 114 surat ini. Al Quran tentu tidak menyebutkan secara detail dan 
jelas bagaimana arsitektur yang islami itu. Walaupun begitu, secara implisit di dalamnya terdapat suatu penjelasan yang menjadi dasar dan acuan tentang bagaimana idealnya suatu lingkungan, bagaimana sistem nilai, batasan dan aturan pergaulan antara pria dan wanita, dan sebagainya. Hal yang tidak kalah penting adalah di dalamnya juga termuat konsep keindahan bangunan, yang dicontohkan dengan menggambarkan keindahan bangunan-bangunan di surga, seperti yang diceritakan di dalam surat al Waqi'ah.

Konsep keindahan yang terwujud dalam berbagai bidang tersebut biasa kita sebut dengan seni dan kesenian. Dalam arsitektur, seni mempunyai posisi yang sangat penting. Bahkan pada awal berkembangnya, keilmuan arsitektur termasuk dalam bidang seni murni, bukan seperti pada saat ini, dimana arsitektur merupakan penggabungan antara ilmu, seni dan teknologi. Arsitektur merupakan sarana untuk mewujudkan wadah bagi aktivitas manusia dengan menggabungkan berbagai sudut pandang keilmuan, termasuk budaya dan tentu saja seni. Dalam Islam, aspek seni dalam kebudayaan Islam harus juga dilihat sebagai ekspresi estetis dari al Quran. Seni Islam tidak lain adalah seni Qurani. Seni Qurani inilah yang nantinya juga akan mendukung terwujudnya arsitektur Islam sebagai salah satu unsur yang penting. Di dalam buku "Seni Tauhid" karya Ismail Raji al Faruqi, terdapat beberapa alasan al Quran dapat menjadi dasar dari karya seni (Al Faruqi, 1999: 3) sebagai berikut:

a. Al Quran dapat berfungsi sebagai penjelas tauhid atau transendensi

b. Al Quran sebagai model seni

c. Al Quran sebagai ikonografi artistik

\section{Seni Ruang dan Arsitektur}

Arsitektur termasuk di dalam seni ruang dalam esensi seni menurut Islam, hal ini dikarenakan arsitektur merupakan seni visual yang mendukung kemajuan peradaban Islam (Al Faruqi, 1999: 158). Di dalam seni ruang, terdapat cabang lain yang termasuk mendukung di dalamnya yaitu seni rupa. Keberadaan seni ruang yang di dalamnya terdapat bidang arsitektur merupakan satu hal yang cukup penting. Hal ini juga didasarkan pada seni dalam pandangan al Quran, sehingga pembangunan fisik peradaban ini senantiasa selalu berlandaskan nilai-nilai Islam dalam al Quran, yang juga berfungsi sebagai landasan pembangunan peradaban yang berupa akhlaq dan perilaku. Hal ini sangatlah penting untuk mewujudkan kembali nilainilai Islam ke dalam tatanan pembangunan peradaban di dunia, yang tidak hanya membangun peradaban secara fisik, tetapi juga secara mental, pola 
pikir, semangat, akhlaq dan pola perilaku yang berlandaskan ajaran Islam yang bersumber pada al Quran.

Semangat untuk kembali pada pandangan dan konsep pembangunan dan keindahan berdasarkan al Quran inilah yang terdapat dalam arsitektur Islam. Setiap karya dalam bidang arsitektur yang merupakan perwujudan fisik dari suatu peradaban, tidak hanya dipandang indah dan megah dari segi material atau fisik saja, melainkan bagaimana esensi keindahan tersebut dapat muncul dari suatu kebersahajaan atau kesederhanaan, atau dapat saja keindahan tersebut memang berasal dari suatu yang megah yang terinspirasi dari keindahan surgawi. Hal yang tidak kalah penting adalah, bagaimana berbagai versi keindahan itu dapat mengingatkan kita akan KemahaBesaran Allah, bahwa Allah adalah Dzat Maha Agung yang patut kita sembah dan menyadarkan esensi kita sebagai hamba Allah.

Pengembangan seni ruang, termasuk di dalamnya arsitektur, berdasar pada nilai-nilai yang terdapat dalam al Quran, apabila diterjemahkan secara fisik, memiliki beberapa ciri utama. Ciri utama yang digolongkan dalam empat kategori tersebut didasarkan pada ciri-ciri utama yang dimiliki semua seni Islam (Al Faruqi, 1999:158), yaitu sebagai berikut:

a. Unit-unit isi

Hal pertama yang harus dimasukkan dalam "seni ruang" Islam adalah seni yang memainkan peran ekstraornamentasi, walaupun seni ini memiliki sifat-sifat rupaan dan ornamentasi, yang memanfaatkan sifat-sifat meruang (spasial) dari volume dan massa.

b. Arsitektur atau struktur dengan ruang interior

Seni ruang termasuk karya seni yang menambahkan ruang interior kepada dimensi horisontal dan vertikal sehingga memberikan kesan kedalaman (depth), volume, dan massa. Inilah seni yang termasuk dalam bidang "arsitektural".

c. Lanskaping (holtikultura maupun akuakultura)

Lanskaping, suatu bentuk seni yang dikembangkan dengan luas dan sangat berhasil oleh bangsa-bangsa Islam, baik itu karya holtikultura yang indah (penanaman dan pemeliharaan tanaman) serta seni akuakultura yang juga kreatif dan indah (ilmu memakai air dengan artistik dalam kanal, kolam, air mancur, dan air terjun).

d. Desain kota dan desa

Penanganan ruang secara estetik ini meliputi pula hubungan antara satu bangunan dengan bangunan lain di dekatnya, dengan ruang terbuka di sekelilingnya, dan dengan kampung, kompleks, desa, perumahan kota, atau 
kota yang ditempati perumahan tersebut. Aspek lingkungan yang terbangun ini tidak kurang pentingnya dalam seni Islam.

Ajaran tauhid yang dapat menstimulasi kesan infinitas dan transendensi melalui isi dan bentuk estetis dapat direpresentasikan dalam karya seni Islam, yang ciri-ciri di dalamnya mengandung kaidah-kaidah sebagai berikut: Abstraksi dalam seni ruang Islami.

Metode abstraksi dalam seni ruang Islami merupakan transfigurasi terhadap alam, yang dibagi menjadi lima kategori, sebagai berikut:

a. Hiasan penutup (overlay)

Hiasan penutup (overlay) juga disebut dengan penutup bahan dasar. Teknik-teknik overlay atau hiasan penutup dalam seni ruang merupakan unsur yang sangat penting yang dipakai oleh sarjana muslim.

b. Transfigurasi bahan

Abstraksi yang dicapai dari transfigurasi bahan dapat kita temukan pada struktur-struktur ruang Islami. Bobot permukaan dinding secara visual diberi kesan ringan dengan penempatan ceruk, pelengkung buntu, jendela, pintu, dan pola-pola dekoratif lain seperti pilar-pilar ramping yang memperkuat dinding, dan kubah dengan lubang dan hiasan yang menyamarkan massa dan bobot bahanbahan pembuatnya seperti bata, batu, atau beton. Selain dekorasi cat, keramik, bata, atau relief plester yang bersifat dua dimensi, juga terdapat hiasan penutup yaitu muqarnas yang berbentuk tiga dimensi.

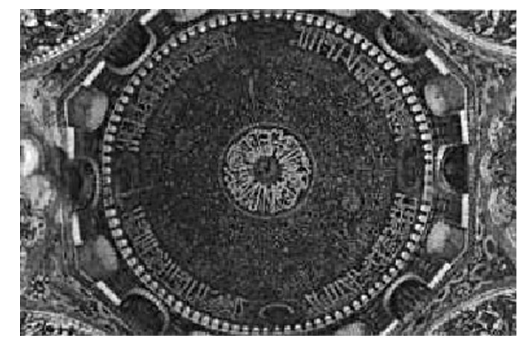

3

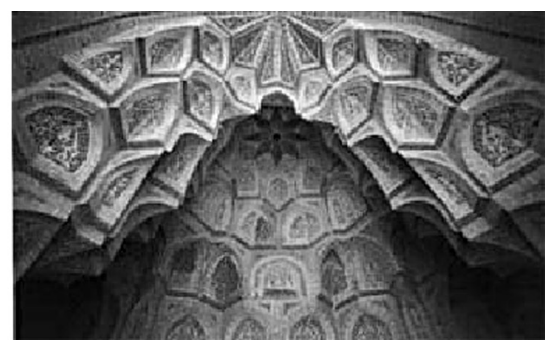

4

Gambar 1. Muqarnas, salah satu hiasan penutup struktur yang berbentuk tiga dimensi, sehingga bahan dasarnya tidak terekspos (Sumber: M.Hattstein \& P.Delius, 2000) dan Gambar 4. Salah satu contoh dekorasi relief sebagai penutup bagian dalam kubah (Sumber: M.Hattstein \& P.Delius, 2000)

c. Transfigurasi struktur

Penonjolan struktur desain suatu karya arsitektur, selalu digemari karena menimbulkan persepsi estetik yang didasarkan atas tauhid. Dalam karya arsitektur Islam, struktur juga dapat berfungsi sebagai pengarah bangunan 
sehingga dapat langsung dinikmati secara temporal, dengan berjalan di sekitar atau menelusup diseluruh kompleks bangunan. Misalnya, ruang yang mempunyai lorong banyak (denah hypostyle) seperti Masjid Cordoba, tidak bisa dinikmati kecuali dengan berjalan pelan melalui seluruh lorong yang didukung oleh hiasan kolom.

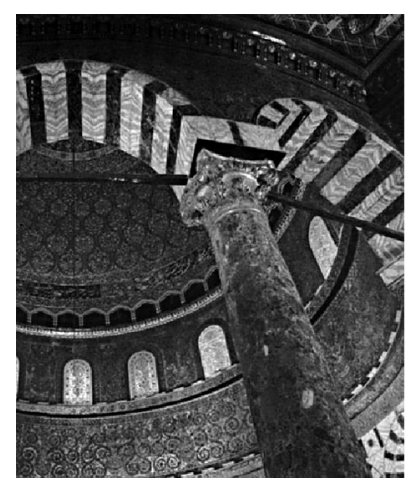

5

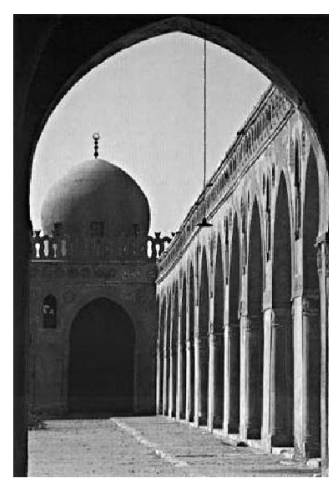

6

Gambar 2. Pola hypostyle pada Masjid Ibnu Tulun, Cairo yang menonjolkan kolomkolom struktur. (Sumber: M.Hattstein \& P.Delius, 2000: 113)

Gambar 3. Dekorasi penghias kolom pada Qubbah Al Shakhrah yang menutup bahan penyusun struktur aslinya.(Sumber: M.Hattstein \& P.Delius.2000, p.66)

\section{d. Transfigurasi uang tertutup}

Transfigurasi ruang tertutup merupakan salah satu cara untuk menonjolkan abstraksi. Hal ini tidak dilakukan dengan menghilangkan dinding pembatas melainkan dengan menghilangkan kesan solid dan terbatas pada ruang, dengan penggunaan dinding terbuka, ceruk, kubah, maupun atap. Hal ini berfungsi untuk membebaskan ruang untuk pergerakan manusia serta persepsi estetik dalam ruang.
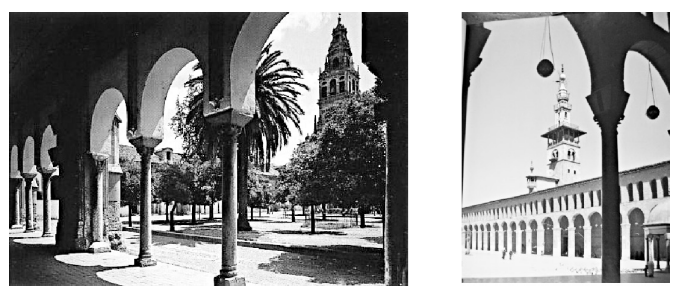

Gambar 4. Penggunaan dinding terbuka dengan deretan kolom pada Masjid Agung Cordoba dan bangunan masjid di Syiria menghilangkan kesan solid dan terbatas pada ruang, karena terdapat hubungan den gan ruang luar. (Sumber: M.Hattstein \& P.Delius, 2000: 221) 
e. Transfigurasi atau ambiguitas fungsi

Ambiguitas fungsi di sini mempunyai maksud bahwa ruang tidak hanya dibatasi untuk satu tujuan penggunaan saja. Kita dapat mengambil sebuah contoh bahwa sahn atau pelataran terbuka yang menjadi ciri dominan dari istana atau masjid, dapat kita temui pada bangunan dengan fungsi lain seperti rumah sederhana, madrasah, hotel, maupun kantor.

\section{Unit/Modul}

Bangunan arsitektural merupakan sejumlah modul atau unit-unit yang dikombinasikan, demikian pula seni ruang, merupakan kumpulan dari modulmodul yang lebih kecil.

\section{Kombinasi suksesif}

Modul-modul ruang dikombinasikan untuk membentuk kombinasi yang lebih besar, misalnya beberapa ruang tempat tinggal, merupakan modul ruang yang paling dasar dikombinasikan dengan pelataran terbuka. Selanjutnya berlanjut dengan kombinasi di atasnya, sehingga menghasilkan rumah hunian, istana, madrasah, atau pun masjid. Kemudian taman, pelataran terbuka begitu seterusnya sampai kombinasi tersebut menjadi sesuatu yang kompleks pada satu tatanan kota. Tidak ada satu pun dari segmen-segmen ini memperoleh prioritas estetik lebih dari yang lain. Sebaliknya, semua bagian tersebut secara integral saling melekat tepat seperti susunan mosaik besar.

\section{Pengulangan}

Unit-unit yang merupakan komponen dari kombinasi ruang tertutup dan terbuka, diulang dalam bentuk identik atau beragam dalam struktur ruang yang saling tambah (aditif). Pengulangan ini juga terjadi dalam unit-unit internal dari masing-masing bangunan dan taman, serta dalam kombinasi bangunan yang membentuk suatu kompleks umum, pribadi, religius, domestik, atau pendidikan, yang merupakan suatu lingkungan urban, desa atau kota yang lengkap.

\section{Dinamisme}

Pemahaman dan apresiasi atas setiap seni ruang dalam Islam harus diperoleh dengan bergerak berurutan melintasi unit-unit ruang. Seni ruang Islami harus dinikmati dengan cara yang dinamis, bukan dalam sekejap waktu yang statis. 
Seperti seni Islam lain, seni ruang harus dipahami dengan mengapresiasikannya satu per satu pada bagian pembentuknya. Contohnya, tiap bangunan terjalin dan berselang-seling dengan lingkungan, sehingga sukar diketahui di mana bangunan ini dimulai dan berakhir. Tidak ada perkembangan arsitektural yang berakhir hanya pada satu klimaks titik estetis.
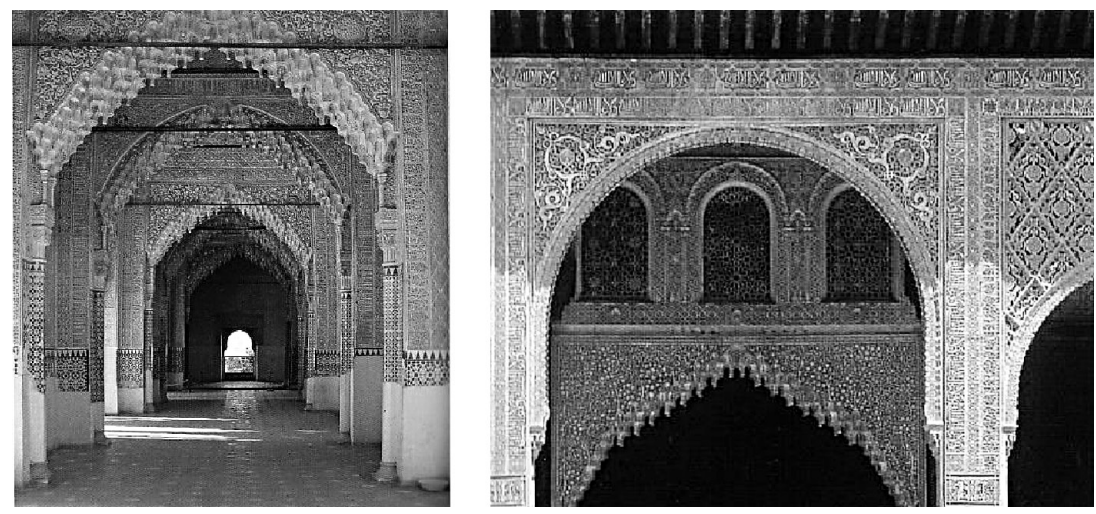

Gambar 5. Desain-desain dekorasi dan tata ruang pada karya-karya arsitektur di negaranegara Islam yang bersifat dinamis. (Sumber: M.Hattstein \& P.Delius, 2000: 292)

\section{Kerumitan}

Dalam seni ruang kerumitan sebagian ditonjolkan dengan pola-pola interior dan dekorasi eksterior yang banyak sekali. Mengamati produk seni yang memiliki kesatuan menyeluruh akan memungkinkan penikmatnya memperoleh pemahaman yang lebih mudah dan cepat dari pengamatan atas karya yang statis dan tidak tumbuh. Oleh karena itu, di dalam karya seni Islam akan selalu ditemukan beberapa kerumitan yang didapat dari susunan yang berlapis-lapis, pengulangan, dinamisme, dan sebagainya. Kota Islam sering diidentikkan dengan lorong bingung (maze, lorong yang berputar membentuk spiral atau sekat) oleh para pengunjung yang tidak memahami esensinya.

Dari beberapa ciri seni Islam yang dapat kita temukan pada karya-karya arsitektur Islam tersebut, dapat kita tarik satu garis merah, bahwa perilaku dalam hal ini perilaku Islami yang disebut dengan akhlakul karimah, salah satunya dapat terbentuk dari lingkungan yang berdasar nilai-nilai Islam. Nilainilai Islam yang kaya serta universal tersebut dapat kita jadikan sebagai satu kekuatan religi yang dapat membangun dan membentuk perilaku Islami. Hal ini juga didasarkan atas salah satu teori perilaku, bahwa lingkungan 
yang dibangun, yang tentunya akan berpengaruh pada desain arsitektur akan membentuk perilaku manusia di dalamnya (architectural determinism).

\section{Simpulan}

Beberapa contoh di atas memberikan satu pelajaran, bahwa perilaku dan akhlak yang dilandasi nilai-nilai Islam yang mendasari lahirnya karya arsitektur Islam, tidaklah dibatasi oleh ruang dan waktu. Kita dapat melihat karya-karya arsitektur Islam di berbagai belahan dunia dengan tujuan yang satu, yaitu untuk beribadah dan berserah diri kepada Allah. Lebih lanjut, terwujudnya beberapa hasil karya arsitektur Islam yang didasari nilai-nilai Islam dapat pula membentuk satu perilaku dan akhlak yang menuju kepribadian dan citra diri Islam yang dibentuk dari lingkungan tersebut.

Arsitektur Islam yang dilandasi oleh akhlak dan perilaku Islami tidak mempunyai representasi bentuk yang satu dan seragam, tetapi arsitektur Islam mempunyai bahasa arsitektur yang berbeda, tergantung dari konteks dimana dan apa fungsi dari bangunan yang didirikan tersebut. Karya arsitektur Islam tidak pula dibatasi oleh wilayah benua dan negara, karena kita akan melihat kekayaan arsitektur Islam dari keragaman tempat yang membawa ciri khas dari wilayah masing-masing negara tersebut. Dari keberagaman tersebut, akhirnya dapat dihadirkan satu kekayaan khazanah arsitektur Islam yang melandasi lahirnya peradaban Islam yang membawa manusia pada rahmatan lil alamin.

\section{Daftar Pustaka}

Al Faruqi, Ismail Raji. 2003. Atlas Budaya Membangun Peradaban Gemilang. Bandung: Mizan.

Al Faruqi, Ismail Raji. 1999. Seni Tauhid Esensi dan Ekspresi Estetika Islam. Yogyakarta: Yayasan Bentang Budaya.

Fikriarini, Aulia \& Eka Putrie, Yulia. 2006. Membaca Konsep Arsitektur Vitruvius dalam Al Quran. Malang: UIN Malang Press.

Faqih, Muhammad. 2006. Peluang dan Tantangan Arsitektur Islam di Era Globalisasi. Makalah disampaikan pada Kuliah Umum untuk Dosen dan Mahasiswa Fakultas Sains dan Teknologi UIN Malang tanggal 15 Maret 2006. 
Faqih, Muhammad. 2007. Integrasi Islam dan Arsitektur. Makalah disampaikan pada Workshop Kurikulum Jurusan Teknik Arsitektur UIN Malang tanggal 29 Maret 2007.

Hattstein, M. dan Delius, P. 2000. Islam Art and Architecture. Konemann: Cologne.

Hershberger, Robert G. 2008. Memprediksi Makna dalam Arsitektur. Arizona State University.

Maslucha, Luluk. 2006. UIN Malang dan Pusat Studi Arsitektur Islam di Indonesia. Malang: UIN Malang Press.

Saoud, Rabah. 2002. Januari. An Introduction to Islamic Architecture. FSTC Limited: Manchester.

Thames \& Hudson. 2004. Architecture and Polyphony Building in The Islamic World Today. London: The Aga Khan Award for Architecture.

www.library.gunadarma.ac.id 